\title{
Ibn Hindu and the science of medicine
}

\author{
M Nasser A Tibi
}

J R Soc Med 2007; 100:55-56

Additional material for this article is available from the James Lind Library website [http://www.jameslindlibrary.org], where this paper was previously published.

Ibn Hindu (Abu al-Faraj 'Ali ibn al-Husayn) flourished during the second half of the 10th century CE (4th century $\mathrm{AH})$, and probably died in $1019 \mathrm{CE}(410 \mathrm{AH}) .{ }^{1}$. Like alRazi a century earlier, ${ }^{2}$ Ibn Hindu was a native of Rayy, near Tehran. He was taught medicine by Abu al-Khayr ibn al-Khammar, and philosophy by Abu al-Hasan 'Ali al'Amiri. Ibn Hindu became a well known medical scholar, and was also a skilful calligrapher and accomplished poet. ${ }^{1}$

Ibn Hindu was known particularly for his teaching ability, and students came to attend his classes from different parts of Persia, attracted by the clear style of writing in his Treatise encouraging the study of philosophy (al-Risala al-Mushawwiqa fi al-madkhal ila al-falsafa). ${ }^{3}$ Ibn Hindu introduces the treatise featured in the James Lind Library - The Key to the Science of Medicine and the Students' Guide (Miftah al-Tibb wa-minhaj al-tullab) _ by noting that he had written it at the request of his students because they had admired his earlier treatise.

Ibn Hindu explains in the book that the task of the physician is to help his patients to gain and maintain health, but not until they have learned proper methods for doing this. His treatise is divided into ten chapters with the following titles:

I On encouraging the study of skills in general, and of the science of medicine in particular

II On the validity of the science of medicine

III On the definition of the science of medicine

IV On the nobility of the science of medicine

$\mathrm{V}$ On the various branches of the science of medicine

VI On the various schools of the science of medicine

VII On the methods by which the science of medicine has been derived

VIII On the enumeration of the sciences which a physician must know in order to be perfect in his profession

IX On the stages a student has to go through in his study of medicine, and a classification of the books written on the subject

$\mathrm{X}$ On medical expressions and definitions

Correspondence to: Mona Nasser, West Ghobadian-No: 4.58-App 4, Afrigha Street, 1968936118, Tehran, Iran.

E-mail: monalisa1n@gmail.com
After noting that medicine consists of theoretical and practical elements (p. 30), Ibn Hindu divides the theoretical elements into three branches: (i) 'the science of natural phenomena, as found in the human body'; (ii) 'the science of causes'; and (iii) 'the science of symptoms and indications'. He adds that:

'. . . everything has a cause and a beginning, and is made of components; you can find the truth only by understanding these things.'

Ibn Hindu then divides causes into two categories (pp. 37-38):

' . . . the first inevitably affects the body and includes the surrounding atmosphere; movement and stillness; foods and drinks; sleep and wakefulness; diarrhoea and constipation; and emotions, such as grief, joy, anger, rage and fear. The second category affects the body but can be avoided, such as the sword, the lion, fire, and the like.'

But he makes clear that this knowledge of theory must be supported by empirical observations. Chapter VII-On the methods by which the science of medicine has been derivedcontains the passages of text reproduced in the James Lind Library (pp. 49-52). In this chapter Ibn Hindu suggests that the science of medicine is derived in four main ways.

\section{Medical knowledge gained 'by accident'}

As examples of knowledge gained by accident, Ibn Hindu quotes the following accounts:

'While walking through the fields, a group of boys picked laurel seeds, and one of them tasted some. He was later bitten by a snake and, when he did not suffer any symptoms, it was realized that the laurel seeds had saved him. This was proof of their usefulness as an antidote and, from that day, they were included in the antidotes for poison.' (p. 50)

And another concerning protection from snake bites, citing Galen:

'A group of people were condemned to death because of a crime they had committed, so the king ordered that
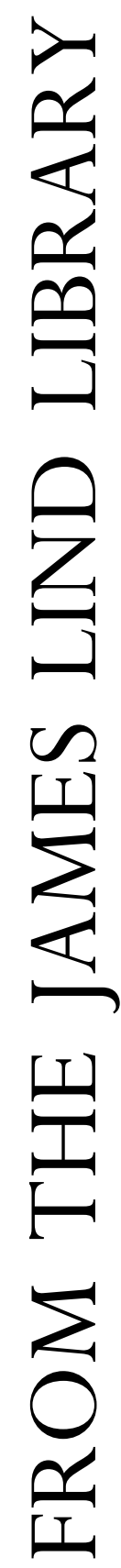
they should be exposed to snakes. However, the poison had no effect on them nor were they harmed by the snake bites. After investigation, it was found out that they had eaten a citron, which had induced resistance to poison. Their tale became a cause of wonder and a legend.' (p. 51)

\section{Medical knowledge gained 'by making experiments with a purpose in mind (mumtahana bi'l-qasd)'}

Of the four ways of deriving the science of medicine suggested by Ibn Hindu, this is the one that comes closest to the prospectively conceived, empirical observations that guide treatment decisions today. Ibn Hindu explains that this entails:

' . . . trying several medicines one by one on bodies with different natures, time after time, then assigning to each [medication] the action that kept recurring by its use.' Thus, '. . . after repeated use, it was proved that sakamuniya gets rid of yellow bile and afitimun gets rid of black bile.' (p. 51)

'Saqamuniya' is scammony, ${ }^{4}$ a twining Asian plant used as a purgative. 'Afitimun' is epithyme, a species of thyme,${ }^{5}$ which is used as a purgative and said to be good for melancholy.

It was probably this experimental approach to testing treatments that led Ibn Hindu to recognize, later in his book, that music could play a useful role in medicine:

'There is a certain way of singing a tune or performing on the drum and flute which arouses sadness, another which brings joy, one relaxing and captivating, another disquieting and disturbing, one which keeps one awake, another which induces sleep. We often prescribe for those who suffer from melancholy or epilepsy a type of [music] that suits their condition and helps them. A physician need not himself be a performer of the drum and the flute or be a skilful dancer, just as he does not need to be a pharmacist or a phlebotomist, but rather he employs these people to aid him in his therapy.' (p. 57)

\section{Medical knowledge gained 'through dreams'}

Even though no-one today would try to deny the power of the mind over the body, the next source for the science of medicine mentioned by Ibn Hindu is likely to appear strange to readers today. He remarks that:
' . . . many patients have dreams in which they are told to take a specific drug and, after waking up, they take that drug and are cured.' (p. 51)

\section{Medical knowledge gained 'by observing animals'}

Ibn Hindu's suggestion that the observation of animals is one of the foundations of the science of medicine suggests a rather different conceptualization of 'animal research' from that about which there is so much debate today! He illustrates the notion that enemas might help to relieve colic with the following example:

'A long-beaked bird living by the seashore appeared to be suffering from colic, so it filled its beak with salt water and emptied it into its anus and thus seemed to rid itself of the malady.' (pp. 51-2)

After setting out these sources of empirical observations, Ibn Hindu notes how they can be strengthened through reason and the application of analogy and logic (p. 58). Indeed, he emphasizes the need for scholars to learn logic in order to distinguish true ideas from false ones, and that a knowledge of logic should precede medical studies (p. 65).

\section{COMMENT}

Ibn Hindu's writings a thousand years ago contain many ideas and examples that appear strange to the modern reader. They are of interest, however, because he makes clear that physicians must proceed beyond logic and theory, and make empirical observations and 'experiments with a purpose in mind'.

Acknowledgments We are grateful to Selma Tibi and Emilie Savage-Smith for comments on an earlier draft of this commentary.

\section{REFERENCES}

1 Lewis B, Menage VL, Pellat Ch, Schacht J, eds. Encyclopaedia of Islam. New Edition, Vol. III. Leiden/London: EJ Brill, 1971

2 Tibi S. Al-Razi and Islamic medicine in the 9th Century. The James Lind Library 2005. Available online at www.jameslindlibrary.org

3 Ibn Hindu. Miftah al-tibb wa-minhaj al-tullab. [The key to the science of medicine and the students' guide]. Mohaghegh M, Daneshpajuh MT, eds. Tehran: Institute of Islamic Studies, McGill University Tehran Branch, in collaboration with Tehran University, 1989

4 Kahl O, ed. Sabur ibn Sahl, al-Aqrabadhin al-Saghir. Dispensatorium Parvum. Leiden: Brill, 1994:254

5 Dozy R. Supplement Aux Dictionaires Arabes. Vol. I. Beyrouth, 1968:29 